\title{
Delação Premiada e uma Sentença Anunciada
}

\author{
Award Delation and an Declared sentence
}

Jhonatan Costa de Almeida

Faculdades de Macapá, Curso de Direito.AM, Brasil. E-mail: jhonatancosta2@hotmail.com

\begin{abstract}
Resumo
O estudo tratará de analisar as imperfeições e fragilidades da técnica jurídica entre delação premiada e a sentença, considerando as formas e limitações que o processo requer. Tendo como objeto de estudo as significações, muito além da semântica, das delações premiadas e o que estes institutos contribuíram para que fosse possível prolatar uma sentença que expõe de forma clara a opção do julgador pela radicalização e uso do direito para fins políticos. Consoante, o problema central deste estudo pode ser expresso na seguinte pergunta: O punitivíssimo promovido, com base nas delações premiadas, pelos protagonistas do sistema judiciário, de forma livre, sem a devida correição e sem leitura consequencial de suas ações, implicaria em uma fragilidade da técnica jurídica? Ademais, este trabalho, também, mostrará a forma de como são, sem generalizar, utilizados os conceitos e noções que seguem uma trilha condenatória, reverberando convicções particulares e presunções formuladas em matéria penal em desconformidade com a análise de fatos em provas, com desorientação, sem guia e sem princípios estáveis, preocupados exclusivamente em escapar dos monstros, ou do monstro, que o ameaçavam, fazendo com que alguns casos vaguem ao acaso no vasto mar da incerteza.
\end{abstract}

Palavra-chave: Colaboração. Organização. Pronuncia. Condenação. Fragilidade Jurídica.

\begin{abstract}
The study will try to analyze the imperfections and weaknesses of the legal technique between the award and the sentence, considering the forms and limitations that the process requires. Having as object of study the meanings, far beyond the semantics, of the awarded statements and what these institutes contributed to make it possible to extend a sentence that clearly exposes the judge's option for radicalization and use of the law for political purposes. Accordingly, the central problem of this study can be expressed in the following question: The punitivism promoted, based on the prizes awarded, by the protagonists of the judicial system, freely, without due correction and without consequential reading of their actions, would imply a fragility of legal technique? In addition, this work will also show how the concepts and notions that follow a condemnatory trail are used, generalizing particular convictions and presumptions formulated in criminal matters in disagreement with the analysis of facts in evidence, with disorientation, without a guide and without stable principles, concerned exclusively with escaping the monsters, or the monster, that threatened him, causing some cases to wander at random in the vast sea of uncertainty.
\end{abstract}

Keyword: Collaboration. Organization. Pronunciation. Conviction. Legal Weakness.

\section{Introdução}

Este estudo pretende mostrar a importância, para a literatura jurídica, de forma simples e de fácil leitura, como o instituto da delação premiada pode, de certa forma, ser considerado como verdade absoluta e, apenas como elementos informativos, poder construir uma sentença.

A delação premiada é instituto que serve para a condução de casos mais complexos como dos crimes organizados. Pela interpretação gramatical, conclui-se que a expressão delação premiada significa uma denúncia ou acusação que resulta positivamente em uma recompensa para quem a fez e, no âmbito jurídico, a delação premiada não foge dessa conclusão semântica.

Consoante, a delação premiada é um instituto que levanta elementos em busca da, até então, 'verdade processual'. No instante em que se oferece ao delator a não agressão à sua liberdade, ou em alguns casos, a diminuição de sua pena, exige-se que este colabore com as autoridades judiciárias apresentando, de certa forma, efetividade na investigação e no processo, dando informações, e não provas, para a solução de um caso criminal, findando em uma sentença.

A sentença, conforme o artigo 381, do Código de Processo Penal, que apresenta os requisitos para a sua validade, é o pronunciamento por meio do qual o juiz põe fim à fase cognitiva do procedimento, bem como extingue a execução. Assim, a sentença é o ato do julgador que extingue o processo com ou sem resolução de mérito, ou que rejeita ou acolhe os pedidos do autor. Sentença é a decisão do magistrado sobre os pedidos formulados na petição inicial, ainda que o processo prossiga.

\section{Desenvolvimento}

\subsection{Metodologia}

A escolha deste objeto, para este estudo, deveu-se à grande repercussão que este tema trouxe para os anais jurídicos e a 
importância destes processos para a literatura, a partir dos entrelaçamentos e conflitos que se estabeleceram entre delação e sentença. Tentando mostrar o raciocínio condenatório que são utilizados nos mais diversos casos, com o objetivo de verificar de que forma, mesmo sabendo que são elementos informativos, as delações podem contribuir para uma sentença, identificando o raciocínio utilizado, mostrando o manejo e os conceitos que serviram como esteira e, do ponto de vista teórico e normativo, evidenciando as possíveis divergências e/ou conflitos.

Dentro desse prisma, também, foram analisados alguns problemas e hipóteses que complementam e subsidiam o objeto deste estudo contribuindo para o enriquecimento didático, em especial, da área do direito criminal, bem como áreas correlatas, não menos importante, exteriozando as imperfeições e fragilidades da técnica jurídica entre delação premiada e a sentença, considerando as formas e limitações que o processo requereu.

Consoante ao objeto deste estudo, foi analisado o punitivíssimo promovido, com base nas delações premiadas, pelos protagonistas do sistema judiciário, de forma livre, sem a devida correição, sem leitura consequencial de suas ações e que implicaria em uma fragilidade da técnica jurídica.

Não obstante, foi analisado o conceito legal de delação premiada e, ainda, se esta é elemento informativo ou prova para uma sentença.

Além disso, analisou-se e fez-se uma crítica ao poder julgador e ao poder acusador, ao momento em que, de forma indiscriminada - entre direito e política -, se utilizam e se justificam de uma necessidade do uso de padrões desviados para tentar dar base sustentatória para situações processuais inéditas de ultraje às normas basilares do Estado Democrático de Direito, mostrando que a corrupção não é só um fenômeno social, político e econômico, é, também, jurídico. Afeta a todos, como um gás que se espalha por todas as instituições democráticas e, de forma consequencial, atrasa o desenvolvimento econômico e torna frágil a governabilidade e, ainda, critica-se como a hegemonia da mídia, tanto televisionada quanto a impressa, utiliza-se de meios escusos e espúrios para convencer a opinião pública sobre a necessidade de um judiciário "justiceiro" contra um "inimigo comum", o que fere diretamente o cerne da democracia, pois a mídia não é apenas uma relação com a imagem, ela é o resultado de uma sociedade que anula a vida em proveito da contemplação.

\subsection{Concepções de Delação Premiada}

A delação premiada não é um instituto novo na história da justiça. Desde os primórdios bíblicos, passando pela Antiguidade Clássica (Roma/Grécia), pela Idade Média, pelos movimentos industriais até os dias de hoje, é possível observar a presença da delação como troca de vantagens de qualquer gênero.

Delação tem origem etimológica no latim: delatio; ónis; denúncia; acusação. Premiada decorre de prêmio, retorno, abrandamento, recompensa, lucro. Porquanto, delação premiada, no sentindo semântico, é um instituto que premia o delator, concedendo-lhe os mais diversos e variados benefícios processuais.

O instituto da delação premiada, no Brasil, encontra-se previsto, na atualidade, em vários dispositivos legais, como descrito no Quadro 1:

Quadro 1 - Dispositivos legais para delação premiada

\begin{tabular}{|c|c|}
\hline Lei & Descrição \\
\hline $8.072 / 90$ & $\begin{array}{l}\text { ispõe sobre os crimes hediondos, prevê no art. } 8^{\circ} \text {, parágrafo único, que: “[...] o participante e o associado que denunciar } \\
\text { autoridade o bando ou quadrilha, possibilitando o seu desmantelamento, terá pena reduzida de um a dois terços". É } \\
\text { cessário referência ao artigo } 288 \text { e parágrafo único do Código Penal. }\end{array}$ \\
\hline $8.137 / 90$ & $\begin{array}{l}\text { Define crimes contra a ordem tributária, econômica e contra as relações de consumo, também tratou da matéria, prevendo no art. } \\
\text { 16, parágrafo único, que com relação aos crimes "[...] cometidos em quadrilha ou co-autoria, o co-autor ou partícipe que através } \\
\text { da confissão espontânea revelar à autoridade policial ou judicial toda a trama delituosa terá a sua pena reduzida de um a dois terços }\end{array}$ \\
\hline $9.269 / 96$ & $\begin{array}{l}\text { Trata da delação premiada em relação ao crime de extorsão mediante sequestro, ao introduzir o } \S 4^{\circ} \text { no art. } 158 \text { do Código } \\
\text { Penal, prevendo a redução da pena de um terço para dois terços àquele que denunciar o crime à autoridade, facilitando a } \\
\text { libertação do sequestrado. }\end{array}$ \\
\hline $9.034 / 95$ & $\begin{array}{l}\text { Dispõe sobre como trata-se crimes organizados e os meios operacionais para a prevenção e repressão desses delitos, em } \\
\text { seu art. } 6^{\circ} \text {, que "[...] nos crimes praticados em organização criminosa, a pena será reduzida de um a dois terços, quando a } \\
\text { colaboração espontânea do agente levar ao esclarecimento de infrações penais e sua autoria". }\end{array}$ \\
\hline $9.807 / 99$ & $\begin{array}{l}\text { Houve a tentativa de uniformizar o tratamento da matéria, prevendo a } 1 \\
\text { diminuição da pena dos acusados que colaborarem de forma voluntária e } \\
\text { confere medidas especiais de segurança para aqueles que colaborarem co }\end{array}$ \\
\hline $9.613 / 98$ & $\begin{array}{l}\text { Dispõe sobre os crimes de lavagem ou ocultação de bens, direitos e valores. Trata da delação premiada no } \S 5^{\circ} \text { do art. } 1^{\circ}: \\
\text { "“[...]§ } 5^{\circ} \text {. A pena será reduzida de um a dois terços e começará a ser cumprida em regime aberto, podendo o juiz deixar } \\
\text { de aplicá-la ou substituí-la por pena restritiva de direitos, se o autor, co-autor ou partícipe colaborar espontaneamente com } \\
\text { as autoridades, prestando esclarecimentos que conduzam à apuração das infrações penais e de sua autoria ou à localização } \\
\text { dos bens, direitos ou valores objeto do crime. }\end{array}$ \\
\hline 11.3 & $\begin{array}{l}\text { Que trata dos crimes relacionados com entorpecentes, traz a delação premiada no artigo } 41 \text {, da seguinte forma: "[...] o } \\
\text { indiciado ou acusado que colaborar voluntariamente com a investigação policial e o processo criminal na identificação dos } \\
\text { demais co-autores ou participes do crime e na recuperação total ou parcial do produto do crime, no caso de condenação, } \\
\text { terá pena reduzida de um terço a dois terços". }\end{array}$ \\
\hline $12.850 / 13$ & $\begin{array}{l}\text { Que versa sobre organizações criminosas, dispõe - em seus dispositivos - sobre delação premiada: "rt. } 4^{\circ} \text { O juiz poderá, } \\
\text { a requerimento das partes, conceder o perdão judicial, reduzir em até } 2 / 3 \text { (dois terços) a pena privativa de liberdade ou } \\
\text { substituí-la por restritiva de direitos daquele que tenha colaborado efetiva e voluntariamente com a investigação e com o } \\
\text { processo criminal, desde que dessa colaboração advenha um ou mais dos seguintes resultados: } \\
\text { I - a identificação dos demais coautores e partícipes da organização criminosa e das infrações penais por eles praticadas; } \\
\text { II - a revelação da estrutura hierárquica e da divisão de tarefas da organização criminosa. }\end{array}$ \\
\hline
\end{tabular}


A sistematização da delação premiada é dar, em troca da delação, benefícios ao delator, tais como: perdão judicial e a redução da pena e, para isto, não existe o requisito de um pré-acordo entre os membros do Ministério Público e a defesa do acusado para que, após entendimento positivo do Parquet, haja a decisão do julgador, porém, é de muita valia o parecer ministerial para a aplicação do instituto, mas, ainda assim, será restrito ao juiz o poder de conceder ou não o perdão judicial.

\subsection{Concepções de Sentença}

O juiz, ao longo da persecução processual, pratica uma série de atos processuais importantes e a sentença seria um desses que, também, é conhecida como decisões definitivas ou sentença em sentido próprio.

A sentença seria um ato judicial que extingue o processo, com ou sem julgamento do mérito, podendo dividir-se em: sentença definitiva e sentença terminativa. A sentença definitiva julga mérito e subdivide-se em duas: sentido estrito, aquela que absolve ou condena o acusado, e em sentido lato, aquela que declara extinta a punibilidade. A sentença terminativa, por sua vez, não julga mérito.

Podem ter classificações, quanto ao órgão, subjetivamente simples (juiz singular), subjetivamente plúrima (colegiado homogêneo) e subjetivamente complexa (colegiado heteregêneo-juri). E, ainda, existe uma classificação, pouco usual, chamada de sentença suicida, ou seja, quando há contradição entre dispositivo e fundamentação. Sua fundamentação legal pode ser encontrada no Código Processual Penal, artigo 381. Possuindo elementos intrínsecos e extrínsecos.

Elementos intrínsecos são compostos por Relatório (incisos I e II), por Fundamentação (inciso III) e Dispositivo (inciso IV e V). Já os elementos extrínsecos são formados pela parte autenticativa (data e assinatura), inciso IV.

Nesta esteira, faz-se necessário, para melhor entender todo o contexto condenatório que o caso requereu, explicar a correlação entre acusação e sentença, para isto, utilizar-se-á como base principiológica o princípio da Correlação entre a imputação e a sentença. Isto é, os fatos narrados na inicial (na denúncia ou na queixa) devem manter relação fidedigna e lógica com a sentença.

Com intuito de alcançar o supramencionado, é dado ao juiz dois instrumentos: emendatio e mutatio libelli, respectivamente art. 383 e art. 384 do CPP. De acordo com emendatio libelli, o juiz, quando da sentença, verificando que a tipificação não corresponde aos fatos narrados na petição inicial, poderá de ofício apontar sua correta definição jurídica. Ressalta-se que na emendatio os fatos provados são exatamente os fatos narrados.

Por outro lado, verifica-se a mutatio libelli, quando o juiz concluir que o fato narrado na inicial não corresponde aos fatos provados na instrução processual; neste caso, deve o juiz remeter o processo ao órgão acusador (ministário público) que deverá aditar a peça inaugural. Ressalta-se que na mutatio os fatos provados divergem dos fatos narrados.

\subsection{Concepções de Processo Penal}

Processo penal, conforme Marques (2009), é um conjunto de princípios e normas que regulam a aplicação jurisdicional do Direito Penal, bem como as atividades persecutórias da Polícia Judiciária, e a estruturação dos órgãos da função jurisdicional e respectivos. Consoante a isto, possui finalidades, e estas são classificadas como Imediatas/Direta e Mediatas/Indiretas. As Imediatas/Diretas são aquelas que fazem valor o ius puniendi (direito de punir) do Estado. As Mediatas/Indiretas resumirse-ão em promover a proteção da sociedade, da paz social e a defesa dos interesses da coletividade.

Nessa esteira, Avena (2014), complementa que se observa que, se a pessoa realizar determinada conduta descrita em um tipo penal incriminador, a consequência desta prática será o surgimento para o Estado do poder-dever de aplicar-lhe a sanção correspondente. Aqui surge, então, o processo penal, como instrumento destinado à realização do jus puniendi do Estado cujo desenvolvimento será regido por um conjunto de normas, preceitos e princípios que compõem o direito processual.

Para melhor elucidação, faz-se necessário exprimir que o processo penal está entre o garantismo e a eficiência. Ou seja, está entre um conjunto de premissas técnicas que envolvem o modo de pensar e atuar as ciências jurídicas, sujeitando o juiz à lei, mas não de maneira exegese, e, sim, de maneira hermenêutica, e, devendo este, ter a responsabilidade de escolher somente os significados válidos, ou seja, compatíveis com as normas constitucionais substanciais e com os direitos fundamentais para que se possa garantir, também, a eficiência.

Surge, então, a necessidade de estabelecer as fontes formais e materiais que compatibilizam o código do processo penal dentro do ordenamento jurídico. Fonte, em seu sentido semântico, traduz em nascente, em origem, em algo primário.

Consoante, as fontes, classificam-se em formais e materiais. Fontes formais correspondem ao modo de expressão do direito processual penal. Na passagem de Bettaglini, citada por Marques (2009), fontes formais são modos de expressão da norma jurídica positiva. Já as fontes materiais são as chamadas fontes materiais ou subastanciais, como, novamente, Marques (2009) cita a fontes materiais são as que constituem a matéria com que é atingido o conteúdo do preceito jurídico.

Não obstante, apesar da confusão e dos conflitos que a doutrina e a jurisprudência têm, ressalta-se a noção e a importância em conhecer o sistema processual que é adotado no Brasil.

No que respeita à ordenação, pretende-se com ela - quando se recorra a formulação muito geral, para evitar qualquer restrição precipitada - exprimir um estado de coisas intrínseco racionalmente apreensível, isto é, fundado na realidade. Já, no que tange à unidade, verifica-se que este fator modifica o que resulta já da ordenação, por não permitir uma dispersão numa 
multitude de singularidades desconexas, antes devendo deixálas reconduzir-se a uns quantos princípios fundamentais.

Desta forma, percebe-se a importância do conceito de sistema para a ciência do direito e, no ramo do direito processual, este conceito fora aplicado e identificaram-se ao longo da história, basicamente, três grupos de sistemas. Embora haja a evidente discussão, mas esta tornar-se-á meramente exaurida por questões de limitações que este estudo trará, serão apresentados os três sistemas básicos: (a) sistema acusatório; (b) sistema inquisitivo; e (c) sistema misto.

O Sistema Acusatório define-se por haver a efetiva separação das funções de perseguir, acusar e julgar. É um sistema que possui seis características: a jurisdição penal é exercida, essencialmente, por tribunais populares, posicionando-se o julgador como um arbitro imparcial entre o acusador e o acusado; persecução penal é exercida por uma pessoa física que não possui qualquer vínculo com os órgãos oficiais de persecução; o acusado é considerado como sujeito de direitos, estando, pois, em posição de igualdade frente ao acusador; procedimento desenvolve-se mediante um debate público, oral, contínuo e contraditório; valoração da prova, impera o sistema do livre convencimento, não estando os juízes subordinados a regras específicas e rígidas quanto à valoração das provas apresentadas; e sentença é o resultado de uma votação, que pode tomar por base a vontade expressa pela maioria ou pela unanimidades dos julgadores. Este é o sistema adotado no Brasil.

O Sistema Inquisitivo é regido pelo princípio inquisitivo, ou seja, pela concentração de poderes na autoridade judicial e na ideia do juiz como protagonista da gestão. É um sistema onde não há separação da função dos sujeitos do processo, ou seja, a função de perseguir, acusar e julgar são centralizadas por uma mesma pessoa.

O Sistema Misto é sistema que é conhecido por sistema napoleônico ou inquisitivo reformado. É um sistema que deriva de um misto de acusatório com inquisitivo.

\subsection{Discussão}

A apresentação e discussão para este estudo será constituída, inicialmente, por autores que ajudarão, com suas obras e doutrinas, a analisar e discutir a importância que estes institutos têm para o ordenamento jurídico brasileiro, bem como a influência que estes têm para os novos processos.

Nessa perspectiva, a contribuição de autores como Beccaria (2017), Novaes (2016), Sanches (2017), Brasileiro (2017), Houassis (1976), Kafka (2006), Madeira (2016), Lenza (2010), entre outros, tornam-se fundamentais, pois trazem luz para entender questões e consequências que a delação tem no processo de sentença. Beccaria (2017) um dos grandes nomes do direito criminal, afirma que é de suma importância, em toda boa legislação, determinar de maneira exata o grau de confiança que se deve dar às testemunhas e à natureza das provas, necessárias para constatar o delito.

Ao enfatizar a função da testemunha, Beccaria (2017) alerta que todo homem médio, isto é, todo homem que tiver certa coordenação em suas ideias e que experimentar as mesmas sensações que os outros homens, poderá ser recebido em testemunho. Porém, a confiança que se lhe der deve medirse pelo interesse que ele tem de dizer ou não a verdade. Isto será uma passagem considerada na aplicação empírica deste estudo.

Talvez a colaboração do co-réu permita a punição de delitos graves em sociedade. Talvez o sistema de delação premiada permita que se aproxime da verdade material sobre determinados crimes, porém não há certeza de que tais objetivos se cumpram, enquanto surge a inexorável certeza de que o sistema em que é incentivada a ação do acusado, em apoio ao Judiciário, produz quebra às garantias constitucionais importantes.

Destarte, o atual ordenamento jurídico brasileiro, guiado por certo discurso político do crime, produz um cenário próprio, não só aos olhos de juristas renomados, de ineficiência e simbolismo. Ao passar dos anos foi sendo produzida uma enxurrada de leis que tratam das mais diversas e, ao mesmo tempo, banais hipóteses de delitos, avançando o poder punitivo do Estado sobre as liberdades individuais, uma espécie de Direito Penal Promocional (SANCHES, 2017). De certa forma, surgem leis que nada têm a ver com as estruturas democráticas, forjadas pelo sofrimento de milhares de pessoas, que entregaram suas vidas em salvar o homem do mito da necessidade e eficácia da abusiva intervenção estatal.

Nessa esteira de banalização das leis e imoralidade das normas jurídicas, tem-se a delação premiada, com uma 'pseudoperfeição' na promessa de maior punição em troca da renúncia pela sociedade de parte de seus direitos, trazendo para uma análise social o verdadeiro dilema ético.

Mais do que um elemento de desintegração social, a delação - e, por conseguinte vulgar, a traição - é, sob a perspectiva da ética, um desvalor, algo que contraria sua essência à concepção de vida moral fundada na dignidade da pessoa humana. Neste sentido, são as palavras do mestre Franco (1992, p. 221):

Dá-se o prêmio punitivo por uma cooperação eficaz com a autoridade, pouco importando o móvel real do colaborador, de quem não se exige nenhuma postura moral, mas antes, uma atitude eticamente condenável. Na equação "custobenefício", só se valora as vantagens que possam advir para o Estado com a cessação da atividade criminosa ou com a captura de outros delinquentes, e não se atribui relevância alguma aos reflexos que o custo possa representar a todo o sistema legal enquanto construído com base na dignidade da pessoa humana.

Gustav Radbruch (2004) diz que o direito e a moral, no conteúdo de suas exigências, correspondem em parte e casualmente. A relação entre ambos, dos domínios de normas, reside muito mais no fato de que na moral, por um lado, é fim do direito, e por outro, e exatamente por isso, é fundamental de sua validade obrigatória.

Percebe-se, então, que delação premiada é, de maneira 
simples e didática, uma espécie de perfídia, e, fazer apologia a qualquer tipo de perfídia, tornar-se-á um atentado aos objetivos expostos no preâmbulo de nossa Constituição Federal, ou seja, um atentado ao Estado Democrático de Direito, onde consolidam-se a fraternidade, harmonia social, justiça, segurança e bem-estar.

Uma prova irrefutável dessa infeliz ligação entre delação e espírito antidemocrático reside, por questões exemplares, nos acontecimentos no tempo da Alemanha Nazista, quando os alemães recebiam, diariamente, em torno de 2 a 3 mil delações, em sua maioria destinadas a expor a origem judaica de compatriotas e os hábitos, considerados pelas nazistas, subversivos dos indivíduos socialmente indesejáveis.

Partindo desse exposto, destacam-se os pensamentos de Kant e Bobbio. Kant dizia que outro é um de nós mesmos em sentido inverso, e que toda e qualquer aproximação somente seria possível mediante os laços de confiança. Talvez isso soe demasiadamente idealista, entretanto, esta deve ser vista não como mero presságio de fantasias criadas em sonhos, mas, consonantes. Bobbio complementou, a isto, dizendo que o verdadeiro entusiasmo refere-se sempre ao que é ideal, ao que é puramente moral e não pode residir no interesse individual. Ou seja, em resumo, tem-se que entender que a confiança transcende a esfera das relações particulares e chega a abarcar todo o corpo social e, como consequência, chegando ao interesse público.

Vive-se, hoje, uma sociedade temerosa, uma sociedade de desconfiança, uma sociedade do ganha-perde, uma sociedade na qual a vida em comum é um jogo cujo resultado é nulo, ou até negativo - a depender do ponto de vista - ("se tu ganhas, eu perco"), uma sociedade propícia à luta de classes, à inveja social, ao fechamento, à agressividade da vigilância mútua.

Consoante a isso, fica evidente que um instituto, como o da delação premiada, traz à tona uma pergunta: delação premiada é mecanismo para desmantelar organizações criminosas ou é um instituto para satisfação de interesses escusos da política? Uma pergunta de fácil resposta. É só olhar o cenário e ver o que existe: são organizações desmanteladas ou pessoas livres e sorridentes após receberem o benefício do tal paraquedas dourado ${ }^{1}$ ?

Diante disso, parece tão claro o ataque que tal instituto oferece aos princípios fundamentais sobre os quais se estrutura o Estado Democrático de Direito. Porém, o descontrole produzido por uma crescente espiral criminosa em conjunto com o aumento da irracionalidade social que, inclusive, contagia operadores do direito faz que seja adotada uma espécie bizarra do direito. Uma espécie simbólica misturada com promocional, ou seja, 'atender' aos clamores da opinião pública e aos desejos espúrios e escusos da política.

Ao analisar a Lei 12.850/13, que dispõe - em seus dispositivos - sobre delação premiada, não obstante ao parágrafo anterior, constata-se, hoje, uma zona cinzenta e uma prática deteriorante e obscura que se estende por todo o processo penal.

Art. $4^{\circ} \mathrm{O}$ juiz poderá, a requerimento das partes, conceder o perdão judicial, reduzir em até $2 / 3$ (dois terços) a pena privativa de liberdade ou substituí-la por restritiva de direitos daquele que tenha colaborado efetiva e voluntariamente com a investigação e com o processo criminal, desde que dessa colaboração advenha um ou mais dos seguintes resultados:

I - a identificação dos demais coautores e partícipes da organização criminosa e das infrações penais por eles praticadas;

II - a revelação da estrutura hierárquica e da divisão de tarefas da organização criminosa.

De fato, é inegável que o agir jurídico pressupõe fins, metas e necessidades interiores e exteriores distintos do agir moral. Mas, sob o ponto de vista do delator, ainda que este agisse convicto da moralidade - como se assim espera - de seu comportamento e denunciasse seus parceiros, violaria uma das premissas do imperativo categórico de Kant - fazer porque deve ser feito e não fazer por inclinação de desejos -, visto que através de sua conduta não resguardaria a dignidade humana, de maneira que estaria usando-a com a finalidade de angariar sua liberdade.

Percebe-se aí, não mais um expediente capaz de colaborar com os procedimentos processuais, mas uma fragilidade e debilidade estatal. Mostra a incapacidade que o Estado tem de prover segurança. Exterioriza a contradição que o instituto traz, ou seja, um instituto que deveria trazer garantia jurídica e procedimental, mas que acaba por ser considerado, como resultado, por favorecer a anomia e a promoção de incerteza e insegurança jurídica, na proporção que chancela os benefícios do paraquedas dourado ${ }^{2}$ ao criminoso confesso.

Ainda nessa esteira, a Lei $12.850 / 13$, em seu artigo $4^{\circ}$, ressalta:

$\S 2^{\circ}$ Considerando a relevância da colaboração prestada, o Ministério Público, a qualquer tempo, e o delegado de polícia, nos autos do inquérito policial, com a manifestação do Ministério Público, poderão requerer ou representar ao juiz pela concessão de perdão judicial ao colaborador, ainda que esse benefício não tenha sido previsto na proposta inicial

Evidencia-se, então, que a estrutura processual brasileira se direciona a passos largos para o caótico desenho, tal como fora dito por Beccaria (2017), de um sistema em que às pessoas processadas não resta alternativa a dizer o que o acusador quer ouvir, sendo verdade ou não, mas o que o acusador quer ouvir, em troca de um possível abrandamento de seu crime, uma espécie de acusação secreta misturada com interrogatórios

1 Um termo criado por Aury Lopes Jr., Alexandre Morais da Rosa e Philipe Benoni Melo e Silva que faz, de forma metafórica, menção às regras contratuais da delação premiada.

2 Um termo criado por Aury Lopes Jr., Alexandre Morais da Rosa e Philipe Benoni Melo e Silva que faz, de forma metafórica, menção às regras contratuais da delação premiada. 
sugestivos e pitadas de tortura psicológica. Triste é o Estado que, de forma desorientada e sem princípios estáveis, tenta escapar, de suas ameaças que o perturbam, de forma a perturbar, para garantir a tranquilidade pública, a de cada cidadão, arrancando do homem fraco e de moral debilitada uma confissão pela qual ele se livrará da dor presente, mas que atenderá aos anseios e desejos políticos que viciaram o processo jurídico e, mais triste ainda, é o Estado que procura fazer nascer a verdade pelos tormentos (benesses da delação premiada), como se essa verdade residisse nas veias e fibras de uma moral desestruturada de um delator, que encontra na luz legal do fim do túnel, a oportunidade de seguir livre e, ao mesmo tempo, atender ao desejo do magistrado em 'achar' um culpado.

Em algumas sentenças, em que houve delação premiada, Franz Kafka ficaria, de certo modo, feliz em ver sua obra ' $O$ Processo $^{3}$ ' ser aplicada de maneira tão exemplar, obra esta onde - nas mais fantasiosas imaginações para uma ficção-, um indivíduo, Josef $\mathrm{K}^{4}$ respeitável funcionário de um banco -, é acordado por oficiais, recebe voz de prisão e, ao longo da história, condenado por um crime não especificado e se vê obrigado a defender-se contra uma acusação que nunca lhe é formalmente apresentada e sobre a qual ele não consegue obter informações.

Notam-se, de alguns casos, as evidentes falhas e tentativas do magistrado/julgador em 'achar' algo que possa justificar e/ou embasar suas fundamentações privadas de vício e estranheza. Percebe-se, então, que em algumas sentenças não são mais um procedimento do Estado punidor, mas, sim, de um Estado que, para livrar-se do que o assombra, põe a cabeça, do acusado, a prêmio Beccaria (2017) dizia que pôr a cabeça de um cidadão a prêmio anula todas as ideias de moral e de virtude. Ou seja, de um lado, as leis punem a traição, de outro, autorizam-na. É apertar, com a mesma mão, os laços de sangue e amizade, fazendo entrar em uma total contradição. É confirmar, sem qualquer dúvida, que a perfídia, em utilizar o instituto da delação premiada como provas, torna qualquer processo um anômalo jurídico. Pois, elemento Informativo e provas são institutos bem diferentes, conforme distinção feita pelo o art. 155 do CPP.

A palavra prova só pode ser usada para se referir aos elementos de convicção produzidos, em regra (exceção: provas cautelares, não repetíveis e antecipadas), no curso do processo judicial, e por conseguinte, com a necessária participação dialética entre as partes, sob o manto do contraditório (ainda que diferido) e da ampla defesa. O contraditório funciona, pois, como verdadeira condição de existência e validade das provas, de modo que, não havendo contraditório, não lhe caberá a designação de provas.

Por outro lado, elementos informativos são aqueles colhidos na fase investigatória, sem a necessária participação dialética das partes. Dito de outro modo, em relação a eles, não se impõe a obrigatória observância do contraditório e da ampla defesa, vez que nesse momento, ainda não há falar em acusados em geral, na dicção do inciso LV do art. $5^{\circ}$ da Constituição Federal. Portanto, não podem ser base, exclusiva, de fundamentação de sentença condenatória, mas que, por sua vez, podem ser utilizadas de maneira subsidiária, como pode ser observado no CPP:

Art. 155. O juiz formará sua convicção pela livre apreciação da prova produzida em contraditório judicial, não podendo fundamentar sua decisão exclusivamente nos elementos informativos colhidos na investigação, ressalvadas as provas cautelares, não repetíveis e antecipadas.

Identificar o raciocínio de algumas sentenças requer uma análise que se despreenda de qualquer elemento que tenha fundamentação legal. Porém, observa-se a subjetividade e consciência e/ou inconsciência de um juiz em uma sentença. Pois, fundamentar a sentença condenatória baseando-se em atos que não são ilícitos comprovadamente, como manda a lei, é mostrar uma espécie de Direito Penal do Autor, em que o sujeito não é julgado pelo que fez, mas pelo que é, ou pelo que parece ser aos olhos do julgador.

Em um Estado Democrático de Direito, sobretudo em um sistema acusatório, muito bem estabelecido no ordenamento jurídico que, a saber, ainda está em vigor, provas que sustentam uma condenação devem passar pelo crivo do contraditório em seu sentindo - mais que jurídico - semântico para que se tornem e se qualifiquem como provas. Ou seja, como fora dito, fora deste rito, serão meras informações.

$\mathrm{O}$ manejo e os conceitos que fundamentam alguns processos, levaram, levam e levarão o direito à deriva, como um náufrago e, consigo, o barco do Estado Democrático de Direito. Nessa prisma, o fim, portanto, já se é esperado e sabido, onde o mais forte sempre ganha, assim como na fábula de La Fontaine ${ }^{5}$, O Lobo e o Cordeiro:

Um cordeiro estava bebendo água num riacho. O terreno era inclinado e por isso havia uma correnteza forte. Quando ele levantou a cabeça, avistou um lobo, também bebendo da água. - Como é que você tem a coragem de sujar a água que eu bebo - disse o lobo, que estava alguns dias sem comer e procurava algum animal apetitoso para matar a fome. - Senhor - respondeu o cordeiro - não precisa ficar com raiva porque eu não estou sujando nada. Bebo aqui, uns vinte passos mais abaixo, é impossível acontecer o que o senhor está falando. - Você agita a água - continuou o lobo ameaçador - e sei que você andou falando mal de mim no ano passado. - Não pode - respondeu o cordeiro - no ano passado eu ainda não tinha nascido. O lobo pensou um pouco e disse: - Se não foi você foi seu irmão, o que dá no mesmo. - Eu não tenho irmão - disse o cordeiro - sou filho único. - Alguém que você conhece, algum outro cordeiro, um pastor ou um dos cães que cuidam do rebanho, e é preciso que eu me vingue. Então ali, dentro do riacho, no fundo da floresta, o lobo saltou sobre o

3 Obra literária de Franz Kafka de 1920 publicada em 1925.

4 Idem, personagem fictício criado por Franz Kafka

5 Jean de La Fontaine (1962 - 1695), escritor francês de poesias e fábulas. 
cordeiro, agarrou-o com os dentes e o levou para comer num lugar mais sossegado.

E, no entanto, há ainda quem julgue pela 'possível' capacidade de revolta do suposto cordeiro. Estabelece-se, então, da maneira que muitos processos são postos, uma nova 'era'. Já se teve a idade antiga, idade média, idade moderna e, agora, idade midiática, ou seja, é a transição de um Estado Democrático de Direito para um Estado midiático penal. Isto porque, nesta 'era', tudo - ou quase tudo - pode (de maneira simultânea) ser ou não ser. O que hoje é, outrora não é mais; o que fora dito, hoje não mais.

O problema, porém, é que, quando isso acontece, o direito cede espaço ao judiciário midiático, onde o julgador é o protagonista de uma trama onde coisas reais são julgadas. Onde este julgador desprende-se das amarras legais que fundamentariam suas decisões para alicerçar seu fundamentos em jornais ou televisões.

Por todos, cita-se, como exemplo, o juiz da sentença do “Caso Lula”, quando este, em um episódio grotesco diz: “(...) saíram denúncias na Folha de São Paulo e no Jornal O Globo que. E, neste momento, Lula retruca: Dr., não me julgue por notícias, mas por provas. Seria cômico, caso não fosse trágico. Fica evidente, com isto, o que Kierkegaard ${ }^{6}$ quis dizer com "existencialismo autêntico", pois é possível que um julgador se torne um julgador avestruz, ou seja, um julgador que enfia a cabeça num buraco para não tomar a conhecimento da realidade e não enfrentar a opinião pública, devido ser sua fonte de conhecimento e acaba não vivendo como si mesmo, mas como a mídia determina que ele viva. Acaba por preterir o ordenamento jurídico aos interesses escusos.

\section{Conclusão}

De forma geral, a utilização dos construtos de concepções de Delação Premiada, de Sentença e de Processo Penal possibilitaram uma compreensão mais sistematizada da delação premiada e da sentença.

Pode-se constatar que certeza de condenações são mero exaurimento. Porém, a dúvida reside, apenas, em tomar conhecimento das razões que levariam tal condenação. Depois de tomadas, percebe-se, em alguns casos, que o magistrado transcende o que se exprime do artigo 155 do Código Processual Penal, onde o juiz tem que formar sua convicção pela livre apreciação da prova produzida em contraditório judicial, não podendo fundamentar sua decisão, exclusivamente, nos elementos de informação colhidos na fase pré-processual, salvos as provas cautelares, não repetíveis e antecipadas.

Consoante, o manejo e os conceitos que são utilizados nas sentença são eivados de convicções particulares e presunções que em nada consubstanciam-se em provas. Um raciocínio condenatório apoiado na exceção, como se o direito pátrio fosse substituído pelo direito estrangeiro traduzindo-se na mais imperfeita interpretação dos conceitos penais.

Não distante, evidencia-se que a não inclinação aos preceitos legais não é um fenômeno social, político e econômico é, também, jurídico. Um mal que permeia por todas as camadas das estruturas e instituições democráticas, dificultando o desenvolvimento e expondo a fragilidade estatal, não vislumbrando-se um entendimento na base fática, mas uma base irrazoável de conclusões jurídicas e condenações baseadas em elementos informativos, uma espécie de 'diversionismo'.

Não obstante a isso, a impressão que a algumas sentenças passam-nos é de que parece não estar preocupada com a legitimidade, nem propriamente com a correção jurídica, mas, sim, com preocupação de efetivar o que já se especulava, o que já se transmitia pela mídia condenatória, o que já se era acordado em interesses escusos e espúrios.

Por fim, é importante sublinhar que, embora o estudo contemple um tema específico, ele permitiu colocar à prova os construtos de concepções de Delação Premiada, de Sentença e de Processo Penal, demonstrando como estes são utilizados nas trilhas condenatórias que, de certa forma, inovam o cenário jurídico, no que se trata de utilização de elementos informativos para uma condenação, sendo esta eivada de vícios ou não, restando-se, assim, apenas a impressão que o magistrado tinha uma causa a ganhar, pois como fora dito, nada de diferente de uma condenação já era esperado, pois, tudo, já está aparentemente orquestrado e sistematicamente estabelecido, seja pelo judiciário e/ou seja pela mídia.

\section{Referências}

AVENA, N. Manual de Processo Penal. São Paulo: Método, 2014.

BECCARIA, C. Dos delitos e das penas. São Paulo: Edipro, 2017.

BRASILEIRO, R. Manual de Processo Penal. São Paulo: JusPodivm, 2017.

CAQUETTI, A. Vade Mecum Juspodivm. Bahia: Juspodivm, 2018.

FOUCAULT, M. Vigiar e punir. São Paulo: Vozes, 2014.

FREDERICO MARQUES, J. Elementos de Direito Processual Penal. São Paulo: Millennium, 2009.

KAFKA, F. O processo. São Paulo: L\&M Pocket, 2018.

LENZA, P. Direto Constitucional Esquematizado. São Paulo: Saraiva, 2010.

MADEIRA, G. Curso de Processo Penal. São Paulo: Revista dos Tribunais, 2016.

NOVAES, A. Muito além do espetáculo. São Paulo: Senac, 2005. RADBRUCH, G. Filosofia do Direito. São Paulo: Coimbra, 2004. SANCHES, R. Manual do Direito Penal: parte especial. São Paulo: JusPodivm, 2017.

SANCHES, R. Manual do Direito Penal: parte geral. São Paulo: JusPodivm, 2017.

SILVA FRANCO, A. Crimes hediondos. São Paulo: Coimbra, 1992. 